\title{
Effects of Dietary Gizzerosine on Contents of Ash and Calcium in the Femur of Young and Ovariectomized Mice
}

\author{
Hiroshi Horikawa ${ }^{1,2}$, Tadahiro Masumura ${ }^{2}$, \\ Emiko WatanABE ${ }^{1}$ and Teru Ishibashi ${ }^{1}$ \\ ${ }^{1}$ Graduate School of Science and Technology, Niigata \\ University, Niigata-shi $950-21$ \\ ${ }^{2}$ Research Laboratory of C. Itoh Feed Mills Co., \\ LTD. Kuroiso-shi 325-01
}

(Received April 23, 1992)

\begin{abstract}
Gizzerosine (2-amino-9-(4-imidazolyl)-7-azanonanoic acid) is a causative substance for the gizzard erosion in chicks. Small amount of dietary gizzerosine causes significant increase in the contents of ash and calcium (Ca) in the femur of chicks. If gizzerosine enhances the bone calcification in mammals as in chicks, it may be effective for prevention of the fragility in pigs and osteoporosis in postmenopausal women. In this study, in order to clarify the effect of dietary gizzerosine on the calcification of bone in growing and ovariectomized mice, as model animals of ospeoporosis, two experiments were conducted. In experiment 1 , the young mice were fed the diets containing gizzerosine at 0,2 and $10 \mathrm{ppm}$ ad libitum. In the mice fed $10 \mathrm{ppm}$ gizzerosine diet, though body weight and femur weight were not affected, the contents of ash and Ca in the femur increased significantly. In experiment 2 , ovariectomized mice were fed diets containing gizzerosine at $0,10,30$ and $100 \mathrm{ppm}$ ad libitum and non-ovariectomized mice were fed a diet without gizzerosine. Though the body weights of ovariectomized mice fed the diet without gizzerosine were significantly heavier, the contents of ash and $\mathrm{Ca}$ in the femur of ovariectomized were lower than those of non-ovariectomized mice. The body weights and contents of ash and $\mathrm{Ca}$ in the fenur of ovariectomized mice increased with increasing dietary gizzerosine levels, reached to maximum and then decreased slightly. Dietary gizzerosine levels did not affect concentrations of plasma $\mathrm{Ca}$ and $\mathrm{pH}$ of the digesta in the duodenum of ovariectomized mice. These results suggested that gizzerosine was effective for acceleration of bone calcification in ovariectomized mice as in chicks. In the case of chicks, gizzerosine decreased $\mathrm{pH}$ of digesta in the gizzard, the low $\mathrm{pH}$ increased the solubility and absorption of $\mathrm{Ca}$ and resulted in enhancement of bone calcification. However, $\mathrm{pH}$ of the digesta in the duodenum of mice was not affected by gizzerosinc. This showed that the enhancement of bone calcification in mice was affected by different mechanism in chicks.
\end{abstract}

Anim. Sci. Technol. (Jpn.) 64 (1): 8-12, 1993

Key words : gizzerosine, calcium content, femur, ovariectomized mice

It has been reported that a small amount of dietary gizzerosine increases contents of ash and $\mathrm{Ca}$ in the femur of chicks ${ }^{2}$. Since these effects of gizzerosine are diminished by adding cimetidine, which is a $\mathrm{H}_{2}$-receptor antagonist of histamine and gizzerosine ${ }^{5)}$, it is suggested that gizzerosine acts to the stimulation of gastric acid secretion. Gastric acid secretion

Anim. Sci. Technol. (Jpn.) 64 (1): 8-12 
increases acidity and causes increase of solubility of $\mathrm{Ca}$ in the digestive tract. As observed in chicks, if gizzerosine enhances the bone calcification in mammals, it may be effective for prevention of the bone fragility in pigs and osteoporosis in postmenopausal women. Because, recently, osteoporosis is an increasingly important public health problem in Japan. In the postmenopausal women, bone mass is lost in the same way as patients after ovariectomy elapsed after the loss of estrogen $^{8)}$. Therefore, in order to certify the effect of gizzerosine on the calcification of bone in mammals, two experiments were conducted.

In experiment 1 , the effect of gizzerosine on the calcification in growing mice was studied and in experiment 2, the effect of gizzerosine on the calcification in ovariectomized mice as an osteoporosis model animal was studied.

\section{Materials and Methods}

Experiment 1: Effects of gizzerosine on contents of ash and $\mathrm{Ca}$ in the femur of growing mice :

Directly after weaning on 21st day after birth, female ICR mice were weighed and allotted to 3 groups of 1 mice with 2 replication each. They were housed in a thermo-controlled room $\left(22.5 \pm 3^{\circ} \mathrm{C}\right)$ and fed diets ad libitum. The basal diet was obtained from Oriental Yeast Co., Ltd. It contained $24.6 \%$ crude protein, $1.2 \% \mathrm{Ca}, 0.9 \% \mathrm{P}$ and $800 \mathrm{IU} / \mathrm{kg} \mathrm{VD}_{3}$. The basal diet was crashed with an ultra centrifugal mill (Mitamura Riken Kogyo) and was screened through the sieve of $1 \mathrm{~mm}$ mesh. After then 2 or $10 \mathrm{ppm}$ of gizzerosine (Ajinomoto Co., INC.) were added to the diet. On the 20th day, mice were weighed individually and sacrificed by chloroform anesthesia. The right femur was taken and weighed after removing the meat. The content of ash in the femur was measured by heating at $500^{\circ} \mathrm{C}$ for $2 \mathrm{hrs}$ in an electric furnace. The ash was added $10 \mathrm{ml}$ of $6 \mathrm{~N} \mathrm{HCl}$ and diluted to the adequate concentration for analysis of $\mathrm{Ca}$ with an atomic absorption spectrophotometer (Hitachi 170-50 A).

Experiment 2: Effects of gizzerosine on contents of ash and $\mathrm{Ca}$ in the femur of ovariectomized mice :

Female 50-day-old ICR mice were weighed, allotted to 5 groups of 4 mice with 2 replication each. The mice of 4 groups were ovariectomized and another one group was not operated. The ovariectomized mice of 4 groups were fed ad libitum the same mash diet as in experiment 1 , to which none, 10,30 or $100 \mathrm{ppm}$ gizzerosine were added. Non-operated group was fed ad libitum a diet without gizzerosine. For ovariectomizing operation, the mice were anesthetized with nembutal. Nembutal (50 $\mathrm{mg} / \mathrm{ml}$ ) was diluted to 10 folds by $0.9 \% \mathrm{NaCl}$ solution and was injected intraperitoneally $(0.08 \mathrm{ml} / \mathrm{g}$ body weight $)$. After being anesthetized, the waist position of mice were opened by surgical scissors and ovaries with a part of uteri were excised. The diets were supplied after $3 \mathrm{hrs}$ of ovariectomizing operation. On the 21 st day, mice were weighed individually and sacrificed. The right feumr was taken and weighed after removing the meat. The contents of ash and $\mathrm{Ca}$ of the femur were determined in the same way as in experiment 1. Digesta in the duodenum of 4 mice were collected as one sample and were washed out by deionized water and made up to $100 \mathrm{ml}$. The $\mathrm{pH}$ of the solution was measured with a glass electrode pH-meter (Horiba, $\mathrm{F}-16$ ). Concentrations of plasma $\mathrm{Ca}$ of 8 mice in each group were measured with a clinical chemistry analyzer (Shimazu CL-7000).

Statistical analysis: Fach value was subjected to one-way analysis of variance ${ }^{6 \text { ? }}$. DUNCAN's multiple range test ${ }^{7)}$ was used to the test for the significant differences among treatment means.

\section{Results}

The results in experiment 1 are shown in Table 1. Supplementation of $2 \mathrm{ppm}$ gizzerosine did not affect significantly the body weight and 
Horikawa, Masumura, Watanabe and Ishibashi

Table 1. Effect of gizzerosine (GZ) on ash and calcium contents in femur of mice in experiment 1

\begin{tabular}{cccccc}
\hline \hline \multirow{2}{*}{ Group } & GZ & Body & \multicolumn{3}{c}{ Femur } \\
\cline { 4 - 6 } & $(\mathrm{ppm})$ & weight $(\mathrm{g})$ & Weight $(\mathrm{g})$ & Ash(\%) & Calcium(\%) \\
\hline 1 & 0 & 22.8 & 0.064 & $32.7^{\mathrm{a}}$ & $11.15^{\mathrm{a}}$ \\
2 & 2 & 22.0 & 0.061 & $32.6^{\mathrm{a}}$ & $11.04^{\mathrm{a}}$ \\
3 & 10 & 23.7 & 0.065 & $34.7^{\mathrm{b}}$ & $11.84^{\mathrm{b}}$ \\
\hline
\end{tabular}

Means for 8 mice each.

Values in the same column with different superscript letters differ significantly at $1 \%$ level.

Table 2. Effect of gizzerosine (GZ) on ash and calcium contents in femur of ovariectomy mice in experiment 2

\begin{tabular}{ccccccc}
\hline \hline Group & Ovary & $\begin{array}{c}\text { GZ } \\
(\mathrm{ppm})\end{array}$ & $\begin{array}{c}\text { Body } \\
\text { weight(g) }\end{array}$ & Weight(g) & $\begin{array}{c}\text { Femur } \\
\text { Ash(\%) }\end{array}$ & Calcium(\%) \\
\hline 1 & - & 0 & $28.3^{\mathrm{b}}$ & 0.0721 & $34.07^{\mathrm{a}}$ & $12.54^{\mathrm{a}}$ \\
2 & - & 10 & $29.6^{\mathrm{bc}}$ & 0.0736 & $34.41^{\mathrm{a}}$ & $13.07^{\mathrm{a}}$ \\
3 & - & 30 & $30.5^{\mathrm{c}}$ & 0.0684 & $38.86^{\mathrm{b}}$ & $14.27^{\mathrm{bc}}$ \\
4 & - & 100 & $29.2^{\mathrm{bc}}$ & 0.0654 & $36.97^{\mathrm{b}}$ & $13.54^{\mathrm{b}}$ \\
5 & + & 0 & $26.1^{\mathrm{a}}$ & 0.0676 & $38.46^{\mathrm{b}}$ & $14.71^{\mathrm{c}}$ \\
\hline
\end{tabular}

Means for 8 mice erch.

Values in the same column with different superscript letters differ significantly at $5 \%$ level.

Table 3. Effect of gizzerosine (GZ) on plasma calcium concentrations and $\mathrm{pH}$ of digesta in duodenum of ovariectomy mice in experiment 2

\begin{tabular}{ccccc}
\hline \hline Group & Ovary & GZ $(\mathrm{ppm})$ & Plamsa $\mathrm{Ca}(\mathrm{mg} / \mathrm{d} l)^{1)}$ & Duodenal $\mathrm{pH}^{2)}$ \\
\hline 1 & $-\cdots$ & 0 & 8.63 & 6.45 \\
2 & - & 10 & 8.78 & 6.34 \\
3 & - & 30 & 8.82 & 6.27 \\
4 & - & 100 & 8.70 & 6.37 \\
5 & + & 0 & 9.25 & 6.37 \\
\hline
\end{tabular}

"Means for 8 mice each.

${ }^{21}$ Means for 2 sample each. One sample was pooled digesta in the duodenum of 4 mice.

femur weight, respectively. However, supplementation of $10 \mathrm{ppm}$ of gizzerosine to the diet caused significant increase in contents of ash and $\mathrm{Ca}$ in the femur of young mice.

The results of experiment 2 are summarized in Tables 2 and 3 . The heavier body weights were observed in ovariectomized mice than in non-ovariectomized mice. The body weights of ovariectomized mice increased furthermore by dietary supplementation of gizzerosine.
They increased until $30 \mathrm{ppm}$ level and then decreased slightly until $100 \mathrm{ppm}$ level. In contrast to the body weights, the contents of ash and calcium in the femur of ovariectomized mice were lower than in the non-ovariectomized mice. The decrease of contents of ash and $\mathrm{Ca}$ in the ovariectomized mice was recovered by supplementation of gizzerosine. Both contents of ash and $\mathrm{Ca}$ in the ovariectomized mice increased until $30 \mathrm{ppm}$ level and then decreased 
slightly until $100 \mathrm{ppm}$ level in the same pattern as observed in the body weights. As shown in Table 3 , the concentrations of plasma $\mathrm{Ca}$ of non-ovariectomized mice were higher numerically, but not significantly than in the ovariectomized mice. Supplementation of gizzerosine had no effect on the concentration of plasma $\mathrm{Ca}$ of ovariectomized mice. There was also no difference in $\mathrm{pH}$ of digesta in the duodenum among the dietary groups.

\section{Discussion}

Gizzerosine induces the gizzard erosion by accelerating gastric acid secretion in broiler chicks ${ }^{5)}$. But the sensitivity of rats for gizzerosine was lower in rats than in chicks. The heated whole fish meal, which contained high levels of gizzerosine and caused gizzard erosion in chicks, had little influence on rat ${ }^{4)}$. The supplementation of $2 \mathrm{ppm}$ of dietary gizzerosine caused significant increase in contents of ash and $\mathrm{Ca}$ in the femur of chicks ${ }^{2)}$. Though no significant effect was found in the body weights and contents of ash and $\mathrm{Ca}$ of a young mice fed the diet supplemented with the same amount gizzerosine, the contents of ash and $\mathrm{Ca}$ in the femur increased significantly by $10 \mathrm{ppm}$ of dietary gizzerosine. This result showed clearly that supplementation of dietary gizzerosine caused the acceleration of bone calcification even in growing mice at a higher level of dietary gizzerosine compared to in chicks.

The body weight of ovariectomized mice fed a diet without gizzerosine was significantly higher. Adversely, contents of ash and $\mathrm{Ca}$ in the femur of ovariectomized mice were significantly lower than those of the nonovariectomized mice. However, the supplementation of dietary gizzerosine caused significant increase in ash and $\mathrm{Ca}$ in the femur of ovariectomized mice.

Since the acceleration of bone calcification by gizzerosine are diminished by adding cimetidine, it is suggested that the effect of gizzerosine acts to the stimulation of gastric acid secretion in chicks. However, there is no report compared the activity of gastric acid secretion of the poultry with that of the mammals. In this report, the acidity of the digesta in the duodenum and concentration of plasma $\mathrm{Ca}$ were not affected by dietary gizzerosine levels. This result suggested that the acceleration of bone calcification by gizzerosine in the ovariectomized mice was controlled by the different mechanism found in chicks. Therefore, it is necessary to clarify this mechanism in mice, and also to study the effect of cimetidine on the bone calcification in mice.

It has been reported that gizzerosine raises the intracellular cyclic adenosine- $3^{\prime}-5$ '-monophosphate (c-AMP) level in the isolated chicken proventriculus $^{3)}$ and osteoclastic bone resorption activity is inhibited by $\mathrm{C}-\mathrm{AMP}^{1}$. Therefore, it is necessary to study the interrelationship of the bone cell c-AMP level and bone calcification enhanced by gizzerosine in mammals and chicks. Gizzerosine might be directly influenced on the osteoblast or the osteoclast activity. And it is also necessary to further investigate that gizzerosine is effective for improvement of the bone fragility in pigs and osteoporosis in postmenopausal women.

\section{References}

1) Chambers, T.J., P.M.J. Mcsheehy, B.M. Thomson and K. Fuller, The effect of calcium regulating hormones and pros. taglandins on bone resorption by osteoclasts disaggregated from neonatal rabbit bones. Endocrinology, 60: 234-239. 1985.

2) Horikawa, H., T. Masumura, S. Hirano, E. Watanabe and T, Ishibashi, Effect of dietary gizzerosine on calcium contents in the femur of chicks. Jpn. Poult. Sci. 29: 361-367. 1992.

3) Ito, Y., H. Terao, T. Noguchi and H. NaITo, Gizzerosine raises the intracellular cyclic adenosine-3, 5-monophosphate level in isolated chicken proventriculus. Poult. Sci., 67 : 1290-1294. 1988.

4) Masumura, T. and M. Sugawara, The influence of heated fish meal inducing poultry gizzard erosion on rats. Jpn. J. 
Zootech. Sci., 53: 743-746. 1982.

5) Masumura, $T$. and $M$. Sugawara, $T$. Noguchi, K. Mori and H. Naito The effect of gizzerosine, a recently discovered compound in overheated fish meal, on the gastric acid secretion in chicken. Poult. Sci., 64 : 356-361. 1985.

6) Snedecon, G.W. and W.G. Cochran, Statistical methods, 6th ed. The lowa Univ.
Press. IA. 1969.

7) Steel, R.G.D. and J.H. Torlle, Principle and Procedure of statistics: A biometrical approach, McGraw-Hill Book Co., Inc., New York, NY. 1980.

8) Takuo, F., M. Furuse, Y. Nakao, T. Matsui and $M$. Shiozawa, calcium and vitamin $\mathrm{D}$ in osteoporosis, J. Bone and Mineral Metal,, 9: 26-30. 1991

\title{
成長中ならびに卵巣摘出したマウスの大腿骨の灰分および カルシウム量に及ぼす食餌ジゼロシンの影響
}

\author{
堀河 博 ${ }^{1,2}$ ・增村忠広 ${ }^{2} \cdot$ 渡辺恵美子 $^{1} \cdot$ 石橋 晃 $^{1}$ \\ 1 新潟大学大学院自然科学研究科, 新潟市 950-21 \\ ${ }^{2}$ 伊藤忠飼料㧣式会社䂙究所, 黑璣市 325-01
}

\begin{abstract}
ジセロシン（2-アミノ-9-(4-イミダゾリル)-7-アザノナノ酸）は猚の筋胃潰序原因物質で, 七ス 夕ミンの $\mathrm{H}_{2}$ 受窄体に作用し，罥酸分泌を刺激する。このジ゙ロシンを少量給与すると触の大腿骨中 の灰行上カルシウム量が有意に増加することが明らかにさ玑ている。この効果か哺乳動物においても認 められれ豚の骨弱や閉経後の女性の荊粗しょう症に対しても有効であることが考えられる，その可能

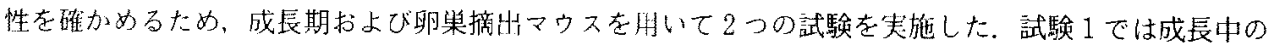
マウスにジゼロシンを0，2および $10 \mathrm{ppm}$ 添加した飼料を給与した， $10 \mathrm{ppm}$ 飼料では体重，大题骨

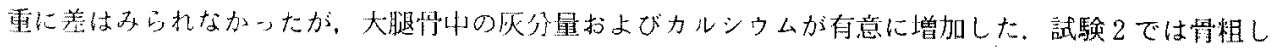

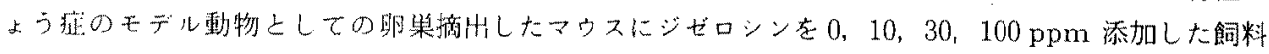
を給与した，対照として莭果を绱出しなかったマウスにジゼロシン無添加の飼料を給与した。ジゼロシ

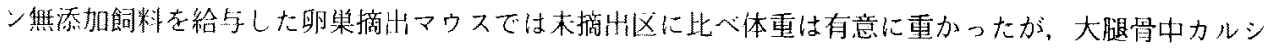

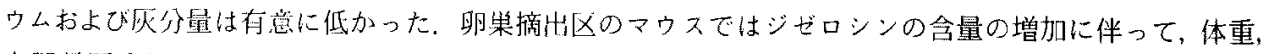
大腿峭灰分およびカルシウム量は增加し，30 ppm を越すとやや威少する傾向がみられた。しかし，シ ゼロシンを給与しても十一指腸の内谷物中の $\mathrm{pH}$ に有意差は热められなかった。こ扎らの結果から，

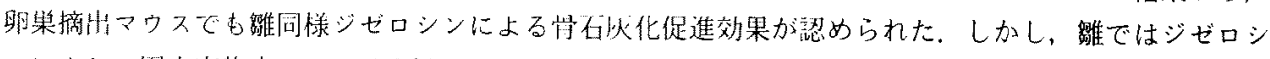
ンにより，棐内容物中の $\mathrm{pH}$ が下がり，そのため, Ca の可溶化と吸収を促進し，その結果，骨石灭化

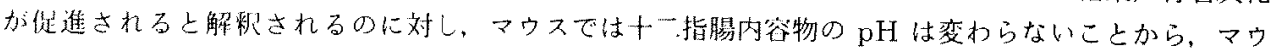

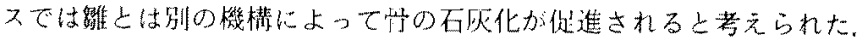

日畜会報, $64(1): 8-12,1993$ 